\title{
ASSOCIATION BETWEEN CONGENITAL MALFORMATION AND NEONATAL AND MATERNAL VARIABLES IN NEONATAL UNITS OF A NORTHEAST BRAZILIAN CITY
}

\author{
Fabíola Chaves Fontoura ${ }^{1}$, Maria Vera Lúcia Moreira Leitão Cardoso ${ }^{2}$
}

\footnotetext{
${ }^{1}$ Part of a dissertation - Newborns with congenital malformations: prevalence and nursing care in a neonatal unit, presented to the Postgraduate Program in Nursing at Universidade Federal do Ceará (UFC), in 2012

${ }^{2}$ Doctoral student of the Postgraduate Program in Nursing at UFC. Fortaleza, Ceará, Brazil. E-mail: fabi_fontoura@yahoo.com. br

${ }^{3}$ Ph.D. in Nursing. Full professor of the UFC Department of Nursing. Fortaleza, Ceará, Brazil. E-mail: cardoso@ufc.br
}

\begin{abstract}
Congenital malformations occur due to genetic, environmental, and mixed factors or unknown causes. This study aimed to investigate the existence of a relationship between the type of congenital malformation and maternal and neonatal variables. This prospective, quantitative study was conducted in three public neonatal units in Fortaleza, Ceará, Brazil. Data were collected from the medical records of 159 malformed neonates and analyzed using the Chi-square test $(\chi 2)$, significance level of $5 \%(p<0.05)$. The majority of the newborns were male, 85 (53\%), 91 (57\%) born full-term, and 82 (52\%) weighed between $2500 \mathrm{~g}$ and 3999g. Malformations of the central nervous and musculoskeletal systems exceeded the other categories. Variables such as gender, gestational age, birth weight, drug use, maternal age, family income, education level, and number of children showed statistically significant associations with the categories of malformations ( $\mathrm{p}<0.05)$. Maternal and neonatal factors have close relationships with the type of malformation, with these data providing support for neonatal nursing care.
\end{abstract}

DESCRIPTORS: Infant, newborn. Congenital abnormalities. Neonatal nursing.

\section{ASSOCIAÇÃO DAS MALFORMAÇÕES CONGÊNITAS COM VARIÁVEIS NEONATAIS E MATERNAS EM UNIDADES NEONATAIS NUMA CIDADE DO NORDESTE BRASILEIRO}

RESUMO: Malformações congênitas ocorrem devido a fatores genéticos, ambientais, mistos ou causas desconhecidas. Objetivouse investigar a existência de relação entre tipo de malformação congênita e variáveis neonatais e maternas. Estudo prospectivo, quantitativo, realizado em três unidades neonatais públicas em Fortaleza-CE, Brasil. Os dados foram colhidos dos prontuários de 159 neonatos malformados, analisados por meio do teste de Qui-quadrado $\left(\chi^{2}\right)$, nível de significância de $5 \%(p<0,05)$. Prevaleceram 85 $(53 \%)$ recém-nascidos do sexo masculino, 91 (57\%) a termo e $82(52 \%)$ com peso entre $2500 \mathrm{~g}$ e $3999 \mathrm{~g}$. Sobressaíram malformações do sistema nervoso central e osteomuscular. Variáveis como sexo, idade gestacional, peso ao nascer, uso de drogas, idade materna, renda familiar, grau de instrução e número de filhos demonstraram significância estatística quando associada às categorias de malformações, com $p<0,05$. Fatores maternos e neonatais apresentam relação com o tipo de malformações, dados estes relevantes para subsidiar o cuidado de enfermagem junto aos neonatos.

DESCRITTORES: Recém-nascido. Anormalidades congênitas. Enfermagem neonatal.

\section{ASSOCIACIÓN DE LAS MALFORMACIONES CONGÉNITAS CON VARIABLES NEONATAIS Y MATERNAS EN UNIDADES NEONATALES DE UNA CIUDAD DEL NORDESTE BRASILEÑO}

RESUMEN: Malformaciones congénitas ocurrir debido a factores genéticos, ambientales, mistos o por causas desconocidas. Se objetivó investigar la relación entre tipo de malformación congénita, variables neonatales y maternas. Estudio prospectivo, cuantitativo, realizado en tres unidades neonatales públicas en Fortaleza-CE, Brasil. Los datos fueron recolectados del sistema de registro de 159 recién nacidos malformados y analizados por medio del test Chi cuadrado $\left(\chi^{2}\right)$, nivel de significancia de $5 \%(p<0,05)$. Prevalecieron 85 $(53 \%)$ recién nacidos del sexo masculino, $91(57 \%)$ a término y $82(52 \%)$ con peso entre $2500 \mathrm{~g}$ y $3999 \mathrm{~g}$. Sobresalieron malformaciones del sistema nervoso central y óseo muscular. Variables como sexo, edad gestacional, peso al nascer, uso de drogas, edad materna, renta familiar, nivel de instrucción y cantidad de hijos demostraron significancia estadística, cuando asociadas a las categorías de malformaciones $(p<0,05)$. Factores maternos y neonatales presentaron relación con el tipo de malformaciones, datos relevantes para el cuidado de enfermería junto al neonato.

DESCRIPTORES: Recién nacido. Anomalías congénitas. Enfermería neonatal. 


\section{INTRODUCTION}

The definition for the term Congenital Malformation (CM), according to the Pan American Health Organization (PAHO) includes any defect in the constitution of any organ or set of organs that determines a structural or functional morphological abnormality present at birth or not, caused by genetic, environmental or mixed factors. ${ }^{1}$ It can be classified as isolated or associated, physical or mental, single or multiple, and of greater or lesser clinical importance. ${ }^{2}$

Despite increasing understanding of the molecular origins of congenital malformations, an average of $50-60 \%$ of cases are due to unknown causes. In the remaining $40 \%$, the common causes can be divided into three categories: genetic (chromosomal abnormalities), environmental (teratogens) and mixed or multifactorial (genetic and environmental). ${ }^{3}$

It can be observed that populations are exposed to the risk of conceiving malformed fetuses, however, the probability of their occurrence will vary according to factors such as race, pre-existing diseases, and socioeconomic and environmental conditions of the pregnant women, among others. ${ }^{4}$

Among the various causes, there are the malformation causing teratogenic factors, which can be classified into the following categories: chemicals agents (licit and illicit drugs, medications and chemical substances), biological agents (infections) and physical agents (ionizing radiation and temperature). ${ }^{5}$

In cases of malformed newborns, more than half could be prevented through the application of primary prevention economic measures. For this, it would be necessary to know the frequency of each specific defect in order to evaluate the impact of a prevention measure and to know the possible causes involved in the specific birth defects. ${ }^{6}$ In several countries, including Brazil, the public health programs concerning congenital malformation preventive actions are related to the fortification of grains and flours with folic acid to reduce the primary occurrence. These changes instituted in Brazil were recommendations suggested by the World Health Organization and Pan American Health Organization, in order to reduce the risk of pathologies that compromise the central nervous system (CNS). ${ }^{7-8}$

In the state of Ceará, the forms of primary prevention in women of fertile age, aiming at the reduction of these occurrences in newborns, are applied. Among them family planning to reduce extreme maternal age, the rubella vaccine, control of the sale of abortive medications such as misoprostol, and combating the use of alcohol, drugs and tobacco can be highlighted. ${ }^{9}$

Because of this problem, greater involvement of researchers in areas related to congenital malformations is necessary, aiming to discover the causal and predisposing factors of these anomalies, as well as their associations, so that health authorities can seek conditions for the reduction of the births rates of malformed children and consequently infant and perinatal mortality, turning to the education of the mothers in order to minimize this public health problem.

It is known that the maternal and child health care policies were imposed from the twentieth century as a result of concerns about birth rates and infant mortality and care for the newborn (NB) in the healthcare area, started as an extension of the action of the obstetric practice. ${ }^{10}$ Thus, the international statistics of congenital malformations should be emphasized, with the prevalence of these ranging from $1 \%$ to $4 \%$, depending on the location and population studied, and the possible association with diverse maternal and neonatal factors. ${ }^{11}$ In Brazil, studies conducted by the Latin American Collaborative Study of Congenital Malformations, the monitoring program of these births, showed a rate of $2.24 \%$ to $5 \%$ of malformed newborns, however, in 2010, the prevalence of abnormalities was $0.8 \%$ in the country, representing an average of two thousand births. ${ }^{12}$

This article aimed to investigate the existence of a relationship between the type of congenital malformation and the neonatal variables (birth weight, gender, and gestational age) and maternal variables (drug use during pregnancy, number of prenatal visits, age, family income, education level, and number of children). ${ }^{13}$

\section{MATERIALS AND METHOD}

This prospective, quantitative study was conducted in three tertiary level hospitals, with one of those classified as a maternity hospital (A) and the other two as general hospitals with maternity units (B and C). They are located in Fortaleza, Ceará, Brazil, providing services through Neonatal Hospitalization Units (NHUs), and are references in neonatal care for the rural and urban population of the municipalities of the state. 
The population consisted of all newborns that received a diagnosis of $\mathrm{CM}$ at birth or within the first 24 hours of life, during the data collection period from January to August 2012. The total number of live births in each study institution during the data collection period was: A - 2,255; $\mathrm{B}-2,133$ and $\mathrm{C}-1,100$. The prevalence of congenital malformations in each institution was: A - 3.3\%; B - 2.1\%; and C-3.6\%, with an mean of 3\% among these, which showed that the six month period of data collection established at each institution, with data from A and B collected simultaneously from January to June 2012 and C from March to August 2012, was satisfactory to highlight the relevance and reliability of the statistical data pertaining to the literature related to the topic in question.

The newborns were obtained from the records of the delivery rooms, and subsequently from the neonatal units, for those cases of medium and high complexity that required monitoring, resulting in a sample of 159 subjects, with 75 recorded in Institution A, 44 in B and 40 in C, after the application of the eligibility criteria of the study.

Therefore, all infants with any congenital anomaly, associated or not, even if death was observed in the delivery room or obstetric surgical center, were included. Newborns that were transferred to the neonatal units, stillborn fetuses, and newborns originating from other institutions, within their first 24 hours of life, were also included. It should be noted that these children should have a birth weight of at least 500 grams, regardless of gestational age (GA), gender, height, number of previous pregnancies, type of delivery, Apgar score, race, and diagnostic and therapeutic approaches.

Newborns diagnosed with $\mathrm{CM}$ after the first 24 hours of life were excluded, in order to limit the sample, as some malformations are diagnosed after the first day of life.

Thus, the data collection was performed from the medical records of the malformed newborns, through a semi-structured form containing maternal variables (maternal age, city of origin, marital status, education, family income, number of pregnancies, births and abortions, type of delivery, number of prenatal consultations, number of living children, number of children with malformations, and use of licit - alcohol and tobacco - or illicit drugs - marijuana, crack, cocaine, and heroin - and neonatal variables (type of congenital malformation, gender, chronological age, gestational age, birth weight, Apgar score, and height), with some of these recorded through open questions and other closed. It should be noted that the mothers were asked about the variable "family income" due to the absence of this in the records. Furthermore, the present study used some variables, as previously described, due to it being part of the Master's degree dissertation previously mentioned.

The data were organized into spreadsheets according to the variable type, using the Excel program and analyzed using the Statistical Package for the Social Sciences (SPSS) version 20.0. Bivariate analysis was carried out, using the chi-square test $\left(\chi^{2}\right)$ with a significance level of $5 \%(p<0.05)$, to evaluate the association between the categories of malformations and the maternal variables (age, use of licit and/or illicit drugs during the pregnancy, number of prenatal consultations, family income, education, number of pregnancies) and neonatal variables (birth weight, gender, gestational age). Descriptive statistics, with simple and absolute frequencies and mean and standard deviation dispersion measures, were applied to the quantitative variables.

The International Statistical Classification of Diseases and Related Health Problems, Tenth Revision (ICD-10), chapter XVII, was used to classify the congenital malformations grouping them into categories, considering their different diagnoses. ${ }^{14}$

The study was approved by the Research Ethics Committee of the institutions studied, under protocol n. 108/2011, respecting the legal and ethical aspects of research involving humans, according to Resolution 466/12 of the National Health Council. The parents or guardians of the malformed newborns signed the Terms of Free Prior Informed Consent (TFPIC), authorizing their inclusion in the study. In the case of adolescent mothers, under 18 years of age, the legal guardians signed the TFPIC.

\section{RESULTS}

The characterization of the 159 newborns affected by congenital malformations showed a prevalence of males, constituting 53\% (85) of the sample, followed by females with $43 \%$ (68) and $4 \%$ (6) indeterminate; the more frequent GA was between 37 weeks and 41 weeks and six days (full-term infants), with 57\% (91), followed by less than 37 weeks of age with $43 \%$ (68), these being evaluated through the Capurro method, which is used by the institutions studied. 
In terms of weight, 3\% (4) were between $500 \mathrm{~g}$ and $999 \mathrm{~g}, 7 \%$ (11) between $1000 \mathrm{~g}$ and $1499 \mathrm{~g}$, $36 \%$ (57) between $1500 \mathrm{~g}$ and $2499 \mathrm{~g}$, 52\% (82) from $2500 \mathrm{~g}$ to $3999 \mathrm{~g}$, these being newborns classified as having normal weight, and 3\% (5) greater than or equal to 4000 grams.

Regarding the maternal data, ages between 19 and 29 years prevailed, with $48 \%$ (76). The majority lived in the city of Fortaleza, Ceará, totaling $52 \%(82)$ of the sample.

In relation to education, with the study time calculated in years, $45 \%$ (72) of the mothers had studied for 10 to 12 years, with this information not being registered in 1\% (1) of the medical records. Considering the family income, there was a greater index in the range between $\mathrm{R} \$ 546.00$ and $\mathrm{R} \$ 800.00$, with 38\% (61). The minimum wage at the time the study was $\mathrm{R} \$ 545.00$.

As presented in Table 1, 40\% (64) of the mothers had less than six consultations, $84 \%$ (134) had not used licit and/or illicit drugs, and 12\% (19) had used marijuana, crack, cocaine, alcohol or tobacco, either in combination or individually. Primiparous mothers were more prevalent, and the frequency of this being the first malformed child was $94 \%$.

Table 1 - Perinatal data of the mothers of malformed newborns in public institutions. Fortaleza, Ceará, Brazil, 2012

\begin{tabular}{lccc}
\hline Variables n=159 & n & \% & Mean \pm SD $^{*}$ \\
\hline No. of prenatal consultations & & & \\
$<6$ & 64 & 40 & $5.94 \pm 2.44$ \\
$\geq 6$ & 91 & 57 & \\
No prenatal care & 1 & 1 & \\
Not registered & 3 & 2 & \\
Use of licit and/or illicit drugs & & & \\
No & 134 & 84 & \\
Yes & 19 & 12 & \\
Not registered & 6 & 4 & \\
No. of pregnancies & & & \\
1 & 67 & 42 & $2.5 \pm 1.96$ \\
2 - 3 & 55 & 35 & \\
$\geq 4$ & 37 & 23 & \\
Order of children with $\mathrm{CM}^{\dagger}$ & & & \\
$1^{\text {st }}$ child & 149 & 94 & $1.03 \pm 0.33$ \\
$2^{\text {nd }}$ child & 9 & 6 & \\
Not registered & 1 & 1 & \\
\hline
\end{tabular}

Source: medical records of the newborns; ${ }^{\mathrm{SD}}=$ Standard Deviation; ${ }^{\dagger} \mathrm{CM}=$ Congenital Malformation.

The categories of congenital malformations are presented in Table 2, according to the ICD-10.
Malformations of the Musculoskeletal System and CNS were more prevalent, with 30\% (84) and $21.1 \%$ (59), respectively.

Table 2 - Categories of congenital malformations in newborns delivered in hospital institutions. Fortaleza, Ceará, Brazil, 2012

\begin{tabular}{lcc}
\hline Malformation categories & $\mathbf{n}$ & $\mathbf{\%}$ \\
\hline Musculoskeletal system CM* & 84 & 30 \\
Central nervous system & 59 & 21.1 \\
Circulatory system & 27 & 9.6 \\
Eye, ear, face and neck CM & 20 & 7.1 \\
Chromosomal abnormalities & 19 & 6.8 \\
Cleft Lip and/or palate & 16 & 5.7 \\
Other digestive CM & 16 & 5.7 \\
Genital organ CM & 15 & 5.3 \\
urinary system CM & 11 & 3.9 \\
Other CM & 11 & 3.9 \\
Respiratory system & 2 & 0.7 \\
\hline
\end{tabular}

Source: medical records of the newborns; ${ }^{*} \mathrm{CM}=$ Congenital Malformations.

When investigating the statistical associations between the categories of congenital malformations and the neonatal variables (Table 3), $p$ values with statistically significant differences were found for the associations between gender and genital organ CMs $(p<0.001)$, as well as between weight and other CMs $(p<0.001)$. For the GA variable, the associations with CMs of the CNS ( $p=0.003)$, CMs of the eye, ear, face and neck $(p=0.004)$, and other CMs ( $p=0.002)$ were found to be significant.

Table 3 - Distribution of $p$ values according to the categories of congenital malformations and the neonatal variables. Fortaleza, Ceará, Brazil, 2012

\begin{tabular}{lccc}
\hline \multirow{2}{*}{ Malformation categories } & \multicolumn{3}{c}{$p$ values* } \\
& Neonatal variables \\
\cline { 2 - 4 } & Gender & Weight & GA $^{\dagger}$ \\
\hline Central nervous system & 0.157 & 0.067 & 0.003 \\
Eye, ear, face and neck & 0.122 & 0.363 & 0.004 \\
Circulatory system & 0.647 & 0.131 & 0.20 \\
Respiratory system & 0.87 & 0.58 & 0.131 \\
Cleft Lip and/or palate & 0.87 & 0.58 & 0.131 \\
Other digestive system CM & 0.588 & 0.90 & 0.996 \\
Genital organs & $<0.001$ & 0.168 & 0.996 \\
Urinary system & 0.645 & 0.772 & 0.246 \\
Musculoskeletal & 0.414 & 0.202 & 0.917 \\
Other CM & 0.285 & $<0.001$ & 0.002 \\
Chromosomal abnormalities & 0.471 & 0.50 & 0.633 \\
\hline
\end{tabular}

${ }^{*} \chi^{2}$ test; ${ }^{\dagger} \mathrm{GA}=$ Gestational Age; ${ }^{\ddagger} \mathrm{CM}=$ Congenital Malformations. 
As presented in Table 4, regarding the associations between the congenital malformation categories and the maternal variables, there was a statistically significant difference with respect to age, drug use, income, education, and number of pregnancies.

Table 4 - Distribution of the $p$ values according to the congenital malformation categories and the maternal variables. Fortaleza, Ceará, Brazil, 2012

\begin{tabular}{lcccccc}
\hline Malformation categories & \multicolumn{5}{c}{$p$ values* } \\
\cline { 2 - 6 } & Age & Drug use & $\begin{array}{c}\text { Number of } \\
\text { consultations }\end{array}$ & Income & Education & $\begin{array}{c}\text { Number of } \\
\text { pregnancies }\end{array}$ \\
\hline Central nervous system & 0.551 & 0.682 & 0.087 & 0.738 & 0.925 & 0.214 \\
Eye, ear, face and neck & 0.991 & $<0.001$ & 0.426 & 0.60 & $<0.001$ & 0.656 \\
Circulatory system & 0.146 & 0.038 & 0.855 & 0.613 & 0.701 & 0.213 \\
Respiratory system & 0.045 & 0.047 & 0.698 & 0.582 & 0.932 & 0.385 \\
Cleft Lip and/or palate & 0.045 & 0.047 & 0.951 & 0.582 & 0.932 & 0.385 \\
Other digestive system CM CM $^{\dagger}$ & 0.402 & 0.337 & 0.666 & 0.796 & 0.687 & 0.108 \\
Genital organs & 0.878 & 0.719 & 0.973 & 0.026 & 0.881 & 0.108 \\
Urinary system & 0.577 & 0.998 & 0.485 & 0.841 & 0.878 & 0.24 \\
Musculoskeletal & 0.749 & 0.76 & 0.859 & 0.205 & 0.864 & 0.045 \\
Other CM & 0.089 & 0.08 & 0.443 & 0.884 & 0.945 & 0.457 \\
Chromosomal abnormalities & 0.046 & 0.821 & 0.11 & 0.823 & 0.558 & 0.888 \\
\hline
\end{tabular}

${ }^{*} \mathrm{X}^{2}$ test; ${ }^{\dagger}$ Congenital Malformations.

\section{DISCUSSION}

After the evaluation of the results presented, it was observed that $53 \%$ of the sample were male, similar to that reported in a study conducted in Maringá-PR from the records of the Live Births Information System (SINASC) and Mortality Information System (SIM) in relation to the births and deaths of malformed fetuses in the period 2000-2007, which showed 32,599 births and 246 $(0.8 \%)$ cases of congenital malformations, with $65.9 \%$ male and the remainder female. However, aiming to verify the association between the maternal age and the maternal sociodemographic, obstetric, and neonatal variables, the authors did not encounter any statistical association between the malformations and gender of the newborn, with Pearson's $p$ value $=0.09 .{ }^{15}$

Regarding the GA, this was also in agreement with the literature, as the present study found the highest prevalence of infants between 37 weeks and 41 weeks and 6 days, with $57 \%$, and a significant association between this variable and the CNS ( $p=0.003)$, eye, ear, face and neck $(p=0.004)$, and other CMs $(p=0.002)$ categories.

In a study conducted in the Caxias do Sul Hospital of Rio Grande do Sul, the mean gestational age of malformed newborns was $37.3 \pm 2.9$, which showed statistical significance, with $p=0.001$, among full-term NBs. ${ }^{16}$
In the present study, the birth weight presented a statistically significant association with the Other CMs category, in which multiple malformations and unspecified malformations stood out. In a case control study with 32 cases of newborns with CNS malformations, a significant association was verified between the weight and the $\mathrm{CM}$, with $p<0.005$ and a mean of $2790 \pm 923$ grams. ${ }^{16}$

It should be noted that some authors have evidenced a significant association between low birth weight and the presence of anomalies, as well as an increased incidence in the number of cases compared to NBs of greater weight. ${ }^{11,17}$

Contradicting the results found in the present study, the study performed in Maringá-Paraná did not find a statistically significant association between congenital anomalies in the newborns and the maternal age variable. However, a statistical significance was highlighted between newborns with congenital anomalies and other variables, such as marital status $(p<0.000)$, education level of the mother $(p=0.0095)$, type of pregnancy $(p=0.0419)$ and number of prenatal consultations $(p=0.0225)$, in which the level of statistical significance was set at $5 \%(0.05) .{ }^{15}$

With regard to family income, a study of information from the Fernandes Figueira National Institute of Woman, Child and Adolescent Health, of the Oswaldo Cruz Foundation (IFF/Fiocruz) re- 
lated to pregnant women at risk, produced results divergent from those described in this study. The Fiocruz study reported that among 3440 mothers, the majority $(62.6 \%)$ reported earning less than or equal to three minimum wages. ${ }^{18}$ It also verified an association between low family income and higher incidence of fetal malformations. Unfavorable maternal socioeconomic conditions, such as low income, low education, and nutritional deficiency have been associated with a higher prevalence of NBs with congenital defects. ${ }^{18}$

The educational level was considered in order to investigate its possible association with the development of fetal malformations, since educational guidance is of paramount importance for the acquisition of knowledge that assists in daily decisions and coping. In a study performed in Campina Grande, Pernambuco to identify the existence of an association between the types of malformation and their risk factors, the authors reported that low educational levels negatively influence the socio-economic conditions and consequently lead to nutritional deficiency, which can bring about the occurrence of fetal malformations. However, maternal education of approximately eight years enables the achievement of a regular socioeconomic status, which, linked to hunger reduction policies implemented by the Brazilian government, will contribute to the reduction of birth defects. ${ }^{19}$

Regarding the education variable, this is in agreement with a study in China, which showed that the level of education is a factor that contributes to obtaining quality prenatal care. It demonstrated that the educational level is positively related to qualified prenatal care, which means that women with more education were more likely to receive quality care.$^{20}$ Thus, it is believed that the higher the level of maternal education, the better discernment of the mother in relation to the need to monitor her pregnancy and care for the child, including those that may present malformed fetuses.

Based on the literature that concerns the variety of $\mathrm{CM}$ associated with other fetal defects, the type of delivery chosen is determined by the defect with the worst prognosis, such as hydrocephalus, open neural tube defects, and abdominal wall defects, which will cause a higher incidence of this type of delivery. ${ }^{13}$ Abdominal delivery was the most frequent due to the newborns presenting high percentages of musculoskeletal and CNS malformations, with these results also verified by other studies showing a higher prevalence of these categories of congenital malformations. ${ }^{16,21}$
Gastroschisis is an example of a CM included in the musculoskeletal category, with its multifactorial etiology integrating various maternal factors. Among these factors, age under 20 years, nutritional deficiencies, tobacco consumption or exposure to smoke, and the use of aspirin in the first trimester, can be mentioned. Risk factors, such as low socioeconomic or sociocultural levels, use of alcohol and drugs, and maternal infectious conditions may also be associated..$^{22}$ However, the results reported here showed no statistically significant associations for the maternal age, family income, drug use and education variables with the Musculoskeletal CM category, with values of $p>0.05$.

In the analysis of the frequency of the categories of congenital malformations presented by the newborns, those with compromise of the CNS constituted $21.07 \%$ of the number of malformations, whether isolated or associated. Other factors are recognized as predisposing and may increase the risk of deformities related to the closure of the neural tube, a CM of the CNS, including Diabetes Mellitus, maternal obesity, early and prenatal exposure to anticonvulsant medications, twin pregnancy, and exposure to Folic Acid antagonists. ${ }^{23}$

In an attempt to find associations between the birth of malformed NBs and the number of consultations performed during the prenatal period, one study evidenced a percentage of $62.5 \%$ of the sample that attended seven or more consultations, with a $p$ value of $0.26 .{ }^{17}$ However, as shown in the results of this study, no statistical significance was found between the CM categories and the number of prenatal consultations, with all the $p$ values being $>0.05$.

With regard to licit and/or illicit drug consumption during pregnancy, it was shown that the majority of the mothers ( $84 \%$ ) did not use any drugs, with only $12 \%$ that did. Alcohol is highlighted due to being considered the most teratogenic agent and the main cause of some non-hereditary congenital malformations that may lead to mental retardation with dysfunctional behavior. ${ }^{24} \mathrm{~A}$ study with malformed newborns showed that 140 (21.4\%) mothers consumed alcohol throughout the entire pregnancy, 159 (24.3\%) for two trimesters, and $355(54.3 \%)$ for one trimester only. ${ }^{24}$

Corroborating the previously mentioned study, ${ }^{24}$ research conducted in nine North American states, through the database of the Pregnancy Risk Assessment Monitoring Survey, aiming to investigate a possible association between the use of alcohol and tobacco by mothers at differ- 
ent stages of pregnancy and the involvement of congenital heart defects, found statistically significant associations, with $p<0.01$, in women who reported consuming alcohol several times during the first trimester of pregnancy and in women who reported excessive consumption of alcohol associated with tobacco use during the same period, based on a statistical association when $p \leq 0.05 .{ }^{25}$ Therefore, there is a need for rigorous prenatal care, in an attempt to reverse possible problems in the health of the mother or fetus, in a timely manner, avoiding unfavorable outcomes. ${ }^{12}$

Regarding the above mentioned study, in relation to the number of pregnancies, $42 \%$ of the sample were primiparous, and $94 \%$ of the patient records contained registrations of this being the first malformed child.

In addition to these data, in a study conducted at the Clinical Hospital in Sao Paulo, 335 mothers of malformed fetuses were interviewed and, in relation to the number of pregnancies and parity, $40 \%$ of the subjects were primiparous, $46.9 \%$ nulliparous, and $76.4 \%$ had experienced an abortion. In $10.4 \%$ of the cases, the mothers had already had a child with CM. In nine cases the recurrence of the same malformation or impairment of the same system was observed: Walker-Warburg Syndrome, PenaShokeir Syndrome, Meckel-Gruber syndrome, Non-immune hydrops fetalis, Cardiopathy, Holoprosencephaly, and CNS malformations. ${ }^{26}$

When associating the categories of congenital malformations to the number of pregnancies, the result was significant, with $p=0.045$ for congenital malformations of the Musculoskeletal System. Another study conducted in the municipalities of the Vale do Paraíba Paulista found no association between birth defects and the number of pregnancies. ${ }^{17}$

The risk of having a child with a congenital defect is variable among women. Researchers have verified that mothers who had already had a malformed child were 2.4 times more likely to have a second affected pregnancy when compared to other pregnant women without a prior history, due to some persistent causal factor. ${ }^{26}$

\section{CONCLUSION}

According to the aforementioned results, among the 159 newborns affected by CM, the majority were male with $53 \%$, followed by female (43\%); the predominant GA was between 37 weeks and 41 weeks and 6 days; and $52 \%$ of the total had an adequate weight of $2500 \mathrm{~g}$ to $3999 \mathrm{~g}$. The most prevalent categories of congenital malformations were those of the Musculoskeletal System and CNS.

A statistically significant association was found between the categories of congenital malformations and some maternal variables (age, drug use, number of prenatal consultations, education, and number of pregnancies) and neonatal variables (GA, weight, and gender), with $p$ values ranging from $<0.001$ to 0.047 .

It was demonstrated that in the sample investigated congenital malformations were directly associated with the maternal and neonatal variables, however, it is necessary to conduct further studies related to the theme covering other Brazilian regions, with different samples in order to verify these results.

The contributions of this study relate to the knowledge of the prevalence of malformations and their relationship with maternal and neonatal issues, as well as the provision of support for better planning of nursing care in neonatal unit, focusing on the NBs and their parents.

The gaps encountered due to the absence of data in the hospital records should be highlighted, both with regard to the documentation of the study units, as well as the patient records of the newborns, which causes biases in the official databases provided to the municipal, state and federal health departments.

The variety of congenital malformation diagnoses and the number of malformations per NB were considered limitations of the study, specifically, causing difficulties in the categorization according to the ICD-10 and in the investigation of the statistical relationships between the established variables.

\section{REFERENCES}

1. Organização Pan-Americana de Saúde (OPAS). Prevenção e controle de enfermidades genéticas e os defeitos congênitos: relatório de um grupo de consulta. Washington (US): OPAS; 1984.

2. Garne E, Dolk H, Loane M, Wellesley D, Barisic I, Calzolari E, et al. Paper 5: surveillance of multiple congenital anomalies: implementation of a computer algorithm in European registers for classification of cases. Birth Defects Res A Clin Mol Teratol. 2011 Mar; 91(suppl.1):44-50.

3. Camelier V, Ramos R, Pereira VF, Reis T, Amorim G, Cerqueira E, et al. Estudo do campo 34 na Bahia e em Salvador: impacto na notificação das malformações congênitas. Gaz Méd Bahia. 2007; 77(supl.1):55-9. 
4. Reis LLAS, Ferrari R. Congenital malformations: demographic profile of mothers and pregnancy conditions. J Nurs UFPE online [Internet]. 2013 Jan [cited 2014 Apr 09]; 8(1):98-106. Available from: http://www.revista.ufpe.br/revistaenfermagem/ index.php/revista/article/view/5349/pdf_4428

5. Gilbert-Barness E. Teratogenic causes of malformations. Ann Clin Lab Sci. 2010; 40(2):99-114.

6. Campaña H, Pawluk MS, López JS. Prevalencia ao nacimiento de 27 anomalías congênitas seleccionadas, em 7 regiones geográficas de la Argentina. Arch Argent Pediatr. 2010 Set-Out; 108(5):409-17.

7. Lumley J, Watson L, Watson M, Bower C. Periconceptional supplementation with folate and/or multivitamins for preventing neural tube defects (Review). Cochrane Database Syst Rev. 2007; (4):1-24.

8. Agência Nacional de Vigilância Sanitária (BR). Resolução RDC n. 344, de 13 de dezembro de 2002. Aprova o regulamento técnico para a fortificação das farinhas de trigo e das farinhas de milho com ferro e ácido fólico, constante do anexo desta Resolução [online]. 2002 [acesso 2013 Jul 15]. Disponível em: http://portal.anvisa.gov.br/wps/ wcm/connect/f851a500474580668c83dc3fbc4c6735/ RDC_344_2002.pdf?MOD=AJPERES

9. Ribeiro EM. Prevenção das doenças genéticas, malformações congênitas e programas de saúde pública no Ceará. Pró-Fono. 2008; 20(supl):66-9.

10. Costa R, Padilha MI. Children's hospital as a reference for at-risk newborn care in Santa Catarina, Brazil (1987-2009). Texto Contexto Enferm. 2010 JulSet; 19(3):469-78.

11. Obu HA, Chinawa JM, Uleanya ND, Adimora GN, Obi IE. Congenital malformations among newborns admitted in the neonatal unit of a tertiary hospital in Enugu, South-East Nigeria - a retrospective study. BMC Res Notes [online]. 2012 [acesso 2013 Jul 02]; 5:177. Disponível em: http:/ / www.biomedcentral. com/1756-0500/5/177

12. Ministério da Saúde (BR). Secretaria de Vigilância em Saúde, Departamento de Análise de Situação de Saúde. Saúde Brasil 2011: uma análise da situação de saúde e a vigilância da saúde da mulher. Brasília (DF): MS; 2012.

13. Fontoura FC. Recém-nascidos com malformações congênitas: prevalência e cuidados de enfermagem na unidade neonatal [dissertação]. Fortaleza (CE): Universidade Federal do Ceará. Programa de PósGraduação em Enfermagem; 2012.

14. Organização Mundial da Saúde. Classificação estatística internacional de doenças e problemas relacionados à saúde. São Paulo (SP): EDUSP; 2008.

15. Melo WA, Zurita RCM, Uchimura TT, Marcon SS. Anomalias congênitas: fatores associados à idade materna em município sul brasileiro, 2000 a 2007. Rev Eletr Enferm [online]. 2010 [acesso 2012 Out 20]; 12(1):73-82. Disponível em: http:/ / www.fen.ufg.br/ fen_revista/v12/n1/pdf/v12n1a09.pdf

16. Pante FR, Madi JM, Araújo BF, Zatti H, Madi SRC, Rombaldi RL. Malformações congênitas do sistema nervoso central: prevalência e impacto perinatal. Rev AMRIGS. 2011 Out-Dez; 55(4):339-44.

17. Pinto CO, Nascimento LFC. Estudo de prevalência de defeitos congênitos no Vale do Paraíba Paulista. Rev Paul Pediatr. 2007 Set; 25(3):233-9.

18. Xavier RB, Jannotti CB, Silva KS, Martins AC. Risco reprodutivo e renda familiar: análise do perfil de gestantes. Ciênc Saúde Coletiva. 2013 Abr; 18(4):1161-71.

19. Brito VRS, Sousa FS, Gadelha FH, Souto RQ, Rego ARF, França ISX. Malformações congênitas e fatores de risco materno em Campina Grande-Paraíba. Rev Rene. 2010 Abr-Jun; 11(2):27-36.

20. Wang D, Shi Y, Donald S, Chang C, Li C. Factors associated with the utilization and quality of prenatal care in western rural regions of China. Health Educ. 2012; 112(1):4-14.

21. Souza ASR, Amorim MMR, Porto AMF. Conditions often associated with caesarean section, with no scientific support. Femina. 2010 Out; 38(10):505-16.

22. Pachajoa H, Urrea MF, Torres J. Gastrosquisis en la unidad de cuidados intensivos neonatal es del Hospital Universitario del Valle, Cali, Colombia, 2000-2004. Iatreia. 2009 Jul-Set; 22(3):213-8.

23. Collins JS, Atkinson KK, Dean JH, Best RG, Stevenson RE. Long term maintenance of neural tube defects prevention in a high prevalence state. J Pediatr. 2011 Jul; 159(1):143-9.

24. Mesquita MA, Segre CAM. Congenital malformations in newborns of alcoholic mothers. Einstein. 2010 Out-Dez; 8(4):461-6.

25. Mateja WA, Nelson DB, Kroelinger CD, Ruzek S, Segal J. The association between maternal alcohol use and smoking in early pregnancy and congenital cardiac defects. J Womens Health. 2012 Jan; 21(1):26-34.

26. Ramos JLAM, Carvalho MHB, Zugaib M. Caracterização sócio demográfica e resultados perinatais das gestações com diagnóstico ultrassonográfico de malformação fetal. Rev Assoc Med Bras. 2009; 55(4):447-51. 